\title{
Selective extraction of lysozyme from a mixture with lactoferrin by ultrafiltration. Role of the physico-chemical environment
}

\author{
Bernard CHAUfER $^{\text {a*}}$, Murielle RABILLER-BAUdRY ${ }^{\mathrm{a}}$, David LUCAS ${ }^{\mathrm{a}}$, \\ Françoise MICHEL ${ }^{\mathrm{b}}$, Martin TIMMER ${ }^{\mathrm{c}}$ \\ ${ }^{a}$ Laboratoire des procédés de séparation, UA 991 Université Rennes-I, INRA, \\ Campus de Beaulieu Bât. 10A, CS 74205, 35042 Rennes Cedex, France \\ ${ }^{\mathrm{b}}$ Laboratoire de recherches de technologie laitière, INRA, 65 rue de Saint-Brieuc, \\ 35042 Rennes Cedex, France \\ ${ }^{c}$ Department of process engineering, NIZO, P.O. box 20, 6710 BA Ede, \\ the Netherlands. Present adress: Timmer technology development and consultancy, \\ Bospoort 11A, 6711 BT EDE, the Netherlands
}

\begin{abstract}
Variation of the physico-chemical environment was used to optimize the selective extraction of lysozyme $\left(14300 \mathrm{~g} \cdot \mathrm{mol}^{-1}\right)$ from a model protein mixture with lactoferrin $\left(77000 \mathrm{~g} \cdot \mathrm{mol}^{-1}\right.$, in monomer form) by ultrafiltration (UF). The system protein-membrane-electrolyte was studied using electrokinetic measurements, in order to determine the charge of both free proteins and fouled membrane, depending on the physico-chemical environment $(\mathrm{pH}$, ionic strength, chemical nature of added salts). This paper shows that, in order to achieve the extraction of a protein from a mixture, the following strategy can be used: the target protein recovered in the permeate has to be uncharged, whereas the retained protein has to be charged in order to exploit the electrostatic repulsion of the membrane partly fouled by the charged protein. This approach was successfully used to achieve the lysozyme/lactoferrin separation with a high selectivity (lysozyme transmission/lactoferrin transmission) using an anionic membrane of pore diameter close to $28 \mathrm{~nm}$. The selectivity of the separation was studied according to the variation of the ionic strength, in the range 1 to $150 \mathrm{mmol} \cdot \mathrm{L}^{-1}$, with either sodium chloride or potassium phosphate. Whereas selectivities were close to 20 in sodium chloride, they were always greater in potassium phosphate and increased up to 120 .
\end{abstract}

ultrafiltration / protein / selectivity / electrophoretic mobility / specific adsorption

\footnotetext{
* Correspondence and reprints. Bernard.Chaufer@univ-rennes1.fr
} 


\section{INTRODUCTION}

The aim of the work reported herein was to optimize the separation of a model binary mixture of an egg white protein, lysozyme (14 $300 \mathrm{~g} \cdot \mathrm{mol}^{-1}, \mathrm{pH}$ of zero charge $(\mathrm{pzc}=$ $\mathrm{pI}=11)$ and a cow milk protein, lactoferrin $\left(77000 \mathrm{~g} \cdot \mathrm{mol}^{-1}\right.$ in monomer form, $\mathrm{pzc}=$ $\mathrm{pI}=8-9)$, using an ultrafiltration process (UF), by variation of the physico-chemical environment (ionic strength and chemical nature of the electrolyte).

To perform the separation of mixture of 2 proteins, according to mechanisms inferred from UF of a single protein, the membrane selectivity (defined as the ratio of the target-protein transmission to the contaminantprotein transmission, here the lysozyme transmission to lactoferrin transmission ratio) can be improved by taking into account the electrostatic interactions occurring between the charged protein and the membrane fouled by the charged protein $[5$, 10]. Therefore, the transmission of the uncharged target protein should be increased whereas that of the contaminant protein should be decreased by its charge because of electrostatic repulsions. The extraction of a protein at its point of zero charge from protein mixture, has been shown to be feasible $[6,10]$.

Lentsch [3] performed the ultrafiltration of lactoferrin $\left(1 \mathrm{~g} \cdot \mathrm{L}^{-1}\right)$ with a sulfonated polysulfone membrane (MMCO $200000 \mathrm{~g} \cdot \mathrm{mol}^{-1}$ ) at pH 6.8 using $\mathrm{NaCl}$ to increase ionic strength. The lactoferrin transmission was lower than $1 \%$ at ionic strength below $50 \mathrm{mmol} \cdot \mathrm{L}^{-1}$. In this range, lactoferrin tends to be in an aggregated form.

Lucas et al. [5] ultrafiltered lysozyme with inorganic zirconia membranes, modified with positively-charged-polyethyleneimine, in relation with the physico-chemical conditions, namely by variation of the ionic strength with different electrolytes, such as $\mathrm{NaCl}$ and potassium phosphate. An empirical correlation between mobility (the electrophoretic mobility of a solute is roughly proportional to the ratio of its apparent charge to its radius [8]) and transmission of lysozyme was shown: the observed transmission varied from 0 to $100 \%$, in close correlation with the net charge of the protein according to its physico-chemical environment. The transmission was higher when lysozyme was uncharged and lower when lysozyme was highly-charged [5]. From these results, Rabiller-Baudry et al. [9] proposed a model based on convection-diffusion and electrophoretic migration (CDE model) accounting for the electrostatic repulsion between the fouled membrane and the protein.

The aim of this study was to achieve the selective extraction of lysozyme from a mixed solution made of lysozyme and lactoferrin. In this study, UF experiments with either single or mixed protein solutions (lysozyme, lactoferrin) were performed with anionic modified zirconia membranes in different physico-chemical environment, i.e. variation of the ionic strength by addition of an electrolyte, and of the chemical nature of the electrolyte (sodium chloride, potassium phosphate). The free proteins and fouled (membrane) grafted zirconia were characterized, through their electrophoretic mobilities.

\section{MATERIALS AND METHODS}

\subsection{Reagents}

Lysozyme was provided by Ovonor S.A. (Trégueux, France), lactoferrin by Sodelac (Recogne, Belgium). Acetonitrile of spectroscopic grade was used for HPLC experiments. All inorganic reagents were of analytical grade. Water used was deionized and filtered $(1 \mu \mathrm{m})$ (Aquadem-Elga, Vern-surSeiche, France).

\subsection{Electrophoretic mobility and HPLC}

The electrophoretic mobilities of single proteins and modified zirconia particles with 
and without proteins in different electrolytes were measured with a Delsa 440 (Coultronics) according to a procedure previously described [5]. The accuracy was $\pm 0.2 \times$ $10^{-8} \mathrm{~m}^{2} \cdot \mathrm{V}^{-1} \cdot \mathrm{s}^{-1}$. Zirconia powder (P 316, Orelis, Saint-Maurice-de-Beynost, France, specific area about $33 \mathrm{~m}^{2} \cdot \mathrm{g}^{-1}$ ) with the same process history as the zirconia on the membrane was used.

The lactoferrin radius was determined by quasi elastic light scattering (Malvern Instruments, Orsay, France, 7032 type) at room temperature. Diffusion coefficients were obtained by extrapolation at infinite dilution. Protein concentration was within $1-20 \mathrm{~g} \cdot \mathrm{L}^{-1}$ and lactoferrin was filtered $(0.1 \mu \mathrm{m})$ twice before use.

The protein concentrations, both in permeate and retentate, were determined by reversed phase high performance liquid chromatography (RP-HPLC) according to [4]. The accuracy of the protein concentration was assessed to 5\%. Therefore, accuracy was about $10 \%$ for protein transmission and $20 \%$ for membrane selectivity.

\subsection{Ultrafiltration}

The ultrafiltration system (PSVR3R, Orelis, formerly Tech-Sep, Saint-Mauricede-Beynost, France) included one tubular multichannel membrane fed by a bilobe pump (SLP 110, Steacma, Epone, France) equipped with a variable frequency drive (R 40, Sew-Usocome, Haguenau, France) and two pressure gauges (Bourdon type, accuracy \pm 0.1 bar). The pressure was adjusted with a membrane valve. During the runs, the temperature of the feed tank solution was controlled and the permeate was recycled to the feed tank to keep the concentration of the feed solution constant (volume reduction ratio VRR $=1$ ). The single protein $\left(1 \mathrm{~g} \cdot \mathrm{L}^{-1}\right)$ and mixed protein $\left(1 \mathrm{~g} \cdot \mathrm{L}^{-1}\right.$ of each protein) solutions were filtered under the following conditions: transmembrane pressure $\Delta P=1.5 \times 10^{5} \mathrm{~Pa}$, tangential flow velocity $U=1 \mathrm{~m} \cdot \mathrm{s}^{-1}$ and controlled temperature $T=12{ }^{\circ} \mathrm{C}$.

\subsection{Calculations}

Transmission $(T r)$ of a protein was defined according to equation (1).

$$
\operatorname{Tr}=\mathrm{Cp} / \mathrm{Cb}
$$

with $C b$ : concentration in the bulk (retentate), and $C p$ : concentration in the permeate.

The membrane selectivity (S) is focused on the target protein (lysozyme) and accordingly defined as the ratio of lysozyme transmission $\left(\operatorname{Tr}^{L Y S}\right)$ to lactoferrin transmission $\left(\operatorname{Tr}^{L F}\right)$ according to equation (2).

$$
S=\operatorname{Tr}^{L Y S} / \operatorname{Tr}^{L F}
$$

The hydraulic resistance due to membrane fouling was calculated according to equation (3):

$$
L p=1 /\left[\eta\left(R_{m}+R_{f}\right)\right]
$$

where $R_{f}\left(\mathrm{~m}^{-1}\right)$ : hydraulic resistance due to overall fouling during UF run; $R_{m}\left(\mathrm{~m}^{-1}\right)$ : hydraulic resistance to water; $L_{p}\left(\mathrm{~L} \cdot \mathrm{h}^{-1} \cdot \mathrm{m}^{2}\right.$. bar $\left.^{-1}\right)$ : hydraulic membrane permeability; and $\eta(\mathrm{Pa} \cdot \mathrm{s})$ : dynamic viscosity of the permeate.

\subsection{Zirconia membranes and zirconia powders}

Multichannel ultrafiltration inorganic membrane (alumina matrix, filtering layer made of zirconia) with $300000 \mathrm{~g} \cdot \mathrm{mol}^{-1}$ molecular mass cut-off was used (Kerasep $300 \mathrm{kD}$, Orelis - this membrane has 7 channels, $2.0 \mathrm{~cm}$ outer diameter and $0.45 \mathrm{~cm}$ channel diameter, $40 \mathrm{~cm}$ length, $0.0396 \mathrm{~m}^{2}$ filtering area). Zirconia powder used to simulate the membrane surface layer was of a similar nature to that on the membrane, and was also provided by Orelis (same process history).

We performed chemical modification of Kerasep membranes and zirconia powder by grafting anionic groups of pyrophosphate type (called A). The home made modified 
zirconia powder is further called $\mathrm{ZrO}_{2}-\mathrm{A}$ and the modified membrane is called $300 \mathrm{kD}-\mathrm{A}$. The modification did not change the hydraulic permeability of the membrane (Lp) to water at $20{ }^{\circ} \mathrm{C}$ which remained at $200 \pm 40 \mathrm{~L} \cdot \mathrm{h} \cdot{ }^{-1} \mathrm{~m}^{-2} \cdot \mathrm{bar}^{-1}$.

\section{RESULTS AND DISCUSSION}

\subsection{Protein and membrane}

characterisation related to the physico-chemical environment

\subsubsection{Lactoferrin radius and molecular weight at varying $\mathrm{NaCl}$ ionic strength}

Table I shows the diffusion coefficients and the calculated Stokes radius at $\mathrm{pH} 7$ determined by using the well-known Stokes-Einstein equation. Accordingly, lactoferrin behaved as a monomer (approximately $77000 \mathrm{~g} \cdot \mathrm{mol}^{-1}$ ) and tetramer (about $320000 \mathrm{~g} \cdot \mathrm{mol}^{-1}$ ) in $\mathrm{NaCl}$ concentrations of 0 and $200-1000 \mathrm{mmol} \cdot \mathrm{L}^{-1}$, respectively. It has also been reported that lactoferrin behaves as a tetramer in the presence of calcium [1].

\subsubsection{Electrophoretic mobility of proteins}

The electrophoretic mobility of lysozyme and lactoferrin versus ionic strength were determined at $\mathrm{pH} 7$ with $\mathrm{NaCl}$ and at $\mathrm{pH} 9$ with potassium phosphate. Lysozyme [5] and lactoferrin at $\mathrm{pH} 7$ are positivelycharged in $\mathrm{NaCl}$ (indifferent electrolyte) as expected from their point of zero charge (Fig. 1). In phosphate at $\mathrm{pH} 9$, lysozyme was positively-charged at ionic strength lower than $10 \mathrm{mmol} \cdot \mathrm{L}^{-1}$, uncharged in the range 10 to $20 \mathrm{mmol} \cdot \mathrm{L}^{-1}$, and negativelycharged over $50 \mathrm{mmol} \cdot \mathrm{L}^{-1}$ because of the specific adsorption of phosphate (Fig. 2). For lactoferrin at $\mathrm{pH} 9$, the roughly constant negative charge in the whole ionic strength range likely means a specific adsorption of the phosphate anion on lactoferrin similar to that observed for $\alpha$-lactalbumin by capillary electrophoresis [8].

Thus, the optimum physico-chemical conditions (uncharged lysozyme and charged lactoferrin) required for the sepa-

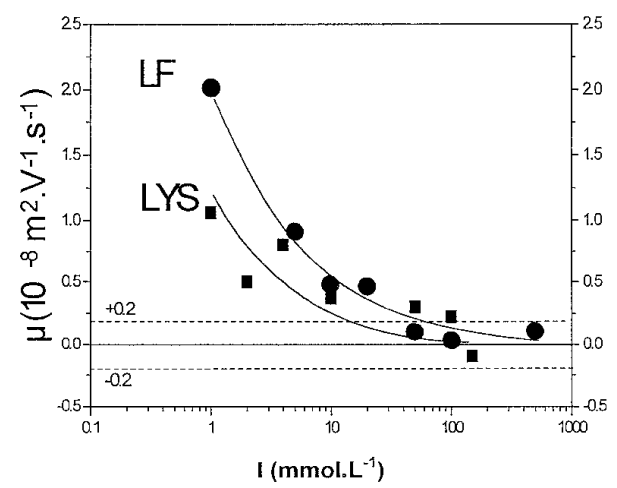

Figure 1. Electrophoretic mobility $(\mu)$ of lysozyme (LYS) and lactoferrin (LF) versus ionic strength (I) of $\mathrm{NaCI}$ at $\mathrm{pH} 7$.

Table I. Molecular weight, diffusion coefficient, and Stokes radius of lactoferrin from quasi-elastic light scattering measurements with varying $\mathrm{NaCl}$ concentration at $\mathrm{pH} 7$.

\begin{tabular}{lccc}
\hline & \multicolumn{3}{c}{ Lactoferrin parameters } \\
\cline { 2 - 4 } \begin{tabular}{l}
$\mathrm{NaCl}\left(\mathrm{mmol} \cdot \mathrm{L}^{-1}\right)$ \\
\cline { 2 - 4 }
\end{tabular} & $\begin{array}{c}\mathrm{MW} \\
\left(\mathrm{g} \cdot \mathrm{mol}^{-1}\right)\end{array}$ & $\begin{array}{c}\text { Diffusion coefficient } \\
10^{-11} \mathrm{~m}^{2} \cdot \mathrm{s}^{-1}\end{array}$ & $\begin{array}{c}\text { Stokes radius } \\
(\mathrm{nm})\end{array}$ \\
\hline 0 & 77000 & 9.6 & 2.2 \\
1000 & 324000 & 4.9 & 4.4 \\
\hline
\end{tabular}




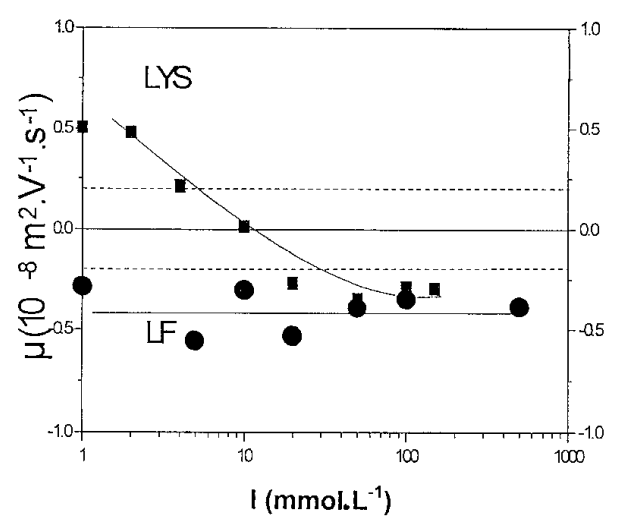

Figure 2. Electrophoretic mobility $(\mu)$ of lysozyme (LYS) and lactoferrin (LF) versus ionic strength (I) of $\mathrm{K}_{2} \mathrm{HPO}_{4}$ at $\mathrm{pH} 9$.

ration of the protein mixture should be: 10-20 mmol. $\mathrm{L}^{-1}$ ionic strength provided by potassium phosphate at $\mathrm{pH} 9$.

\subsubsection{Electrophoretic mobility of zirconia particles fouled with protein}

The electrophoretic mobility of $\mathrm{ZrO}_{2}-\mathrm{A}$ particles with and without the protein was measured at constant $\mathrm{pH}$ and various ionic strengths (data not shown). Such experiments were performed to simulate the protein fouling at the membrane surface layer. It was ascertained that the free protein imposed its charge/potential to the proteinfouled-material, as already found from measurements of mobility of zirconia particles [5] and membrane streaming potential [7]. The fouled membrane is always charged similarly to the free protein.

\subsection{UF of mixture of lysozyme and lactoferrin $(50 / 50 \mathrm{w} / \mathrm{w})$}

\subsubsection{UF of single protein solutions}

Preliminary ultrafiltration of single protein solutions was achieved in $\mathrm{NaCl}$ at $\mathrm{pH} 7$ as a function of increasing ionic strength:
Table II. Fouling of the $300 \mathrm{kD}-\mathrm{A}$ membrane expressed as the ratio $R_{f} / R_{m}$ (accuracy $20 \%$ ) for UF of single and mixed protein solutions with varying ionic strength in $\mathrm{NaCl}$ at $\mathrm{pH} 7$.

\begin{tabular}{lccc}
\hline & \multicolumn{3}{c}{$\mathrm{I}\left(\mathrm{mmol} \cdot \mathrm{L}^{-1}\right)$} \\
\cline { 2 - 4 } protein solution & 20 & 100 & 1000 \\
\hline Lysozyme (Lys) & 7.8 & 5.8 & 3.4 \\
Lactoferrin (LF) & 7.6 & 7.3 & 3.8 \\
mixture (Lys + LF) & 8.5 & 6.9 & 3.0 \\
\hline
\end{tabular}

lysozyme and lactoferrin transmission increased and the fouling decreased (Tab. II).

In potassium phosphate at $\mathrm{pH} 9$, in the case of a constant fouling, the curve of the transmission of lysozyme plotted against the ionic strength showed a maximum for a ionic strength of $10-20 \mathrm{mmol} \cdot \mathrm{L}^{-1}$ [5]. On the contrary, lysozyme transmission with the $300 \mathrm{kD}$-A membrane increased with ionic strength as the fouling decreased in phosphate at $\mathrm{pH} 9$. Consequently, it appears that with the $300 \mathrm{kD}$-A membrane, the decrease of overall fouling overcomes the electrostatic repulsion allowing the lysozyme transmission to remain high and even to increase at ionic strength larger than $50 \mathrm{mmol} \cdot \mathrm{L}^{-1}$.

\subsubsection{UF of proteins in mixture}

Figures $3 \mathrm{a}$ and $3 \mathrm{~b}$ show transmissions of lysozyme and lactoferrin, in a mixture, versus ionic strength using either $\mathrm{NaCl}$ or potassium phosphate.

Lysozyme transmission in the protein mixture increased from a few percent to about $70 \%$, with increasing ionic strength. At $\mathrm{pH}$ 9, the transmission of slightly-charged lysozyme was better than that in $\mathrm{NaCl}$ at $\mathrm{pH} 7$, despite the fact that membrane fouling being slightly higher in the phosphate olution (not shown). In $\mathrm{NaCl}$ at $\mathrm{pH} 7$, membrane fouling remained equivalent to that of UF using single protein solutions (Tab. II). 

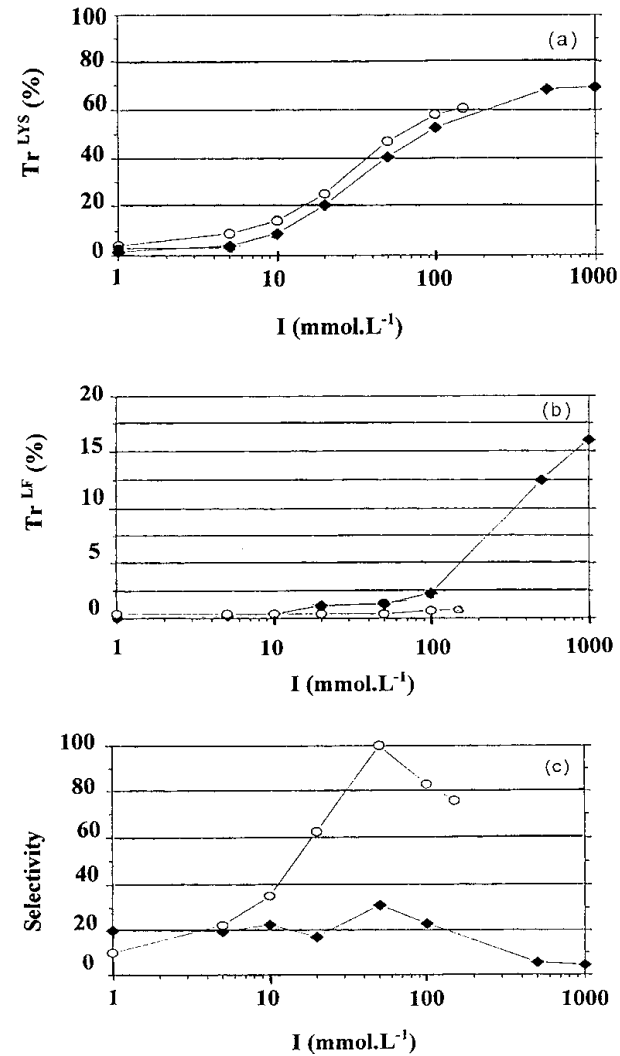

Figure 3. Lysozyme/lactoferrin ultrafiltration versus the ionic strength (I) controlled by $\mathrm{NaCI}$ $(\diamond, \mathrm{pH} 7)$ or $\mathrm{K}_{2} \mathrm{HPO}_{4}(\mathrm{O}, \mathrm{pH}$ 9). (a) Lysozyme transmission (Tr LYS); (b) Lactoferrin transmission (Tr LF); (c) membrane selectivity according to equation (2).

Lactoferrin transmission at $\mathrm{pH} 7$ was lower than $2.5 \%$ at ionic strength up to $100 \mathrm{mmol} \cdot \mathrm{L}^{-1} \mathrm{NaCl}$; its transmission was limited to $15-20 \%$ in $1 \mathrm{~mol} \cdot \mathrm{L}^{-1} \mathrm{NaCl}$ likely due to the lactoferrin tetramer formation. At pH 9 in phosphate, the transmission of negatively-charged-lactoferrin in its most likely monomer form was lower than $0.7 \%$ (estimated from HPLC detection limit) in the range 1 to $150 \mathrm{mmol} \cdot \mathrm{L}^{-1}$ ionic strength.

Figure $3 \mathrm{c}$ shows that the membrane selectivity (Eq. (2), dimensionless ratio) was about $23( \pm 7)$ up to $100 \mathrm{mmol} \cdot \mathrm{L}^{-1} \mathrm{NaCl}$ and about 5 over $500 \mathrm{mmol} \cdot \mathrm{L}^{-1} \mathrm{NaCl}$. At $\mathrm{pH} 9$ when the ionic strength in phosphate was $10 \mathrm{mmol} \cdot \mathrm{L}^{-1}$ or higher, the membrane selectivity was in the range 30-100. An optimum selectivity could be reached between 20 and $50 \mathrm{mmol} \cdot \mathrm{L}^{-1}$ ionic strength, close to the range 10 to $20 \mathrm{mmol} \cdot \mathrm{L}^{-1}$ expected from electrophoretic mobilities of single proteins.

Even though the UF procedure, carried out at VRR =1, was not appropriate for the suitable evaluation of purity of lysozyme in the permeate, it is worth observing that the instantaneous purity of lysozyme in the permeate reached $95 \%$ (selectivity close to 20 ) and $99 \%$ (selectivity close to 70 ) in $\mathrm{NaCl}$ and potassium phosphate, respectively, starting from an initial purity of $50 \%$.

The very high maximum purity of lysozyme in the permeate may be related to the tetramer form of lactoferrin at such high ionic strengths which overcomes the decrease of electrostatic repulsion between free lactoferrin and the fouled membrane, despite the decrease of the fouling.

\section{CONCLUSION}

Enhanced membrane separation of two proteins in solution can be achieved when the target protein transmitted through the membrane and recovered in the permeate is uncharged and the protein to be retained is charged in order to be electrostatically repulsed by the fouled-membrane. The modified membrane carrying initially a negative charge decreased the fouling due to the negatively-charged protein.

This study demonstrated the possibility of using the apparent isoelectric point (iep), related both to the $\mathrm{pH}$ and ionic strength for separation of two protein species based on specific adsorption of electrolyte ions.

Similar results were obtained for separating a mixture of lysozyme and ovotransferrin of white egg [2]. 


\section{ACKNOWLEDGEMENTS}

The authors thank the Conseil Régional de Bretagne for D. Lucas Ph.D. grant, EEC (contract AIR2-CT93-1207) for financial support and Orelis (Rhodia, Eco-services) for providing Kerasep membranes.

\section{REFERENCES}

[1] Bennet R.M., Bagby G.C., Davis J., Calcium dependent polymerisation of lactoferrin, Biochem. Biophys. Res. Commun. 101 (1981) 88-95.

[2] Chaufer B., Rabiller-Baudry M., Lucas D., Michel F., Role of electrostatic forces in ultrafiltration of lysozyme, application to enhanced extraction of lysozyme with lactoferrin or ovotransferrin, Euro-membrane 99, September 19-22, Leuven, Belgium, Book of abstracts, Vol. 2, Posters (1999) 269-270

[3] Lentsch S., Ultrafiltration et électro-ultrafiltration : mécanismes impliqués dans le fractionnement des mélanges albumine-lactoferrine et albumine-poly(éthylène glycol), thèse, Université Paul-Sabatier, Toulouse, France (1993).

[4] Lucas D., Ultrafiltration de protéines par des membranes inorganiques modifiées en relation avec l'environnement physico-chimique, thèse, Université Rennes-I, France (1997).

[5] Lucas D., Rabiller-Baudry M., Michel F., Chaufer B., Role of the physico-chemical environment on ultrafiltration of lysozyme with modified inorganic membrane, Colloids Surfaces A: Physicochem. Eng. Aspects 136 (1998) 109-122.

[6] Nakao S., Osada H., Kurata H., Tsuru T., Kimura S., Separation of proteins by charged ultrafiltration membranes, Desalination 70 (1988) 191-205.

[7] Nyström M., Pihlajamäki A., Ehsani N., Characterization of ultrafiltration membranes by simultaneous streaming potential and flux measurements, J. Membrane Sci. 87 (1994) 245-256.

[8] Rabiller-Baudry M., Bouguen A., Lucas D., Chaufer B., Physico-chemical characterization of proteins by capillary electrophoresis, J. Chromatogr. B 706 (1998) 23-32.

[9] Rabiller-Baudry M., Chaufer B., Aimar P., Bariou B., Lucas D., Model of convection-diffusion-electrophoretic migration, Application to ultrafiltration of lysozyme at various $\mathrm{pHs}$ and ionic strengths, J. Membrane Sci. (to be published).

[10] Saksena S., Zydney A.L., Effect of solution pH and ionic strength on the separation of albumin from immunoglobulins ( $\mathrm{IgG}$ ) by selective filtration, Biotechnol. Bioeng. 43 (1994) 960-968. 